\title{
Gas Exchange in Caryocar Brasiliense Cambess Seedlings in Water Deficit Conditions
}

\author{
Silvana de Paula Quintão Scalon ${ }^{1}$ (D) 0000-0003-2024-7695 \\ Flávia Mitsuko Kodama ${ }^{1}$ (1) 0000-0002-1651-3068 \\ Daiane Mugnol Dresch ${ }^{1}$ (D) 0000-0003-2287-5783 \\ Zefa Valdivina Pereira ${ }^{1}$ (1) 0000-0003-3344-3249 \\ Rosilda Mara Mussury ${ }^{1}$ (1) 0000-0002-8961-9146 \\ Lourenço Quintão Scalon ${ }^{1}$ (i) 0000-0001-7149-0527
}

\begin{abstract}
In this study, we assessed the gas exchange in Caryocar brasiliense seedlings in water deficit conditions and their capacity to recover after rehydration. We assessed plant photosynthetic rates, internal carbon concentrations, stomatal conductance, transpiration rates, water-use efficiency, instantaneous carboxylation efficiency, chlorophyll index, and photosystem II quantum efficiency. All gas exchange parameters were reduced after the suspension of irrigation. Seedling photosynthetic rates approached zero after 12 days. The equilibrium was reestablished in all variables 11 days after re-initiating irrigation, with the exception of internal $\mathrm{CO}_{2}$ concentration and stomatal conductance. Exposure of seedlings to water stress resulted in drastically reduced photosynthetic processes. This reduction occurred due to the limitation of stomatal conductance and low rubisco carboxylation efficiency but not to irreversible damage photosystem II. All of these parameters demonstrated recuperation with rehydration, but only the photosynthetic rates reached initial control values.
\end{abstract}

Keywords: hydric stress, native fruit, Pequi, Caryocaceae.

\section{INTRODUCTION}

Cerrado (Neotropical Savanna) is the second largest Brazilian biome and, according to a review by Klink \& Machado (2005), it demonstrates great biodiversity with more vascular plants than most regions of the world. However, these authors also noted that rapid destruction of Cerrado ecosystems is occurring. By 2004 , approximately $55 \%$ of the total area of this biome had been deforested or transformed by anthropogenic actions. Therefore, it is relevant to better understand the abiotic factors that can affect natural regeneration and thus improve reforestation programs of native Cerrado species to further restore and sustain the Cerrado ecosystem.

Water deficit alters plant physiological processes, mainly the gas exchange, thus limiting photosynthetic processes and the synthesis of organic solutes (and consequently the growth and primary production of plants) as carbon absorption is restricted (Chartzoulakis et al., 2002). During the dry season, seedlings of woody Cerrado species have been observed to present photosynthetic rates near to zero, probably because of severe water loss related to transpiration (Franco, 2006; Mariano et al., 2009).

Although measurements of gas exchange, as regulated by stomatal movements, are important to determine photosynthetic rates, they are not efficient in evaluating the deleterious effects of stress on chloroplasts (Durães et al., 2005). However, reductions in photosynthetic activities due to environmental stress are the result of the photosystem II activity inhibition and they can be evaluated as diminishing chlorophyll fluorescence (Camejo et al., 2005).

A number of researchers have examined the effects of water deficits on different plant species to determine their tolerance mechanisms (Bento et al., 2016; Franco, 2006; Gonçalves et al., 2009; Junglos et al., 2016; Mariano et al., 2009; Medrano et al., 2002; Pacheco et al., 2011; Parry, 2002). The results of these investigations have been useful in arboreal

${ }^{1}$ Universidade Federal da Grande Dourados (UFDG), Dourados, MS, Brasil 
species plantation projects and they could be used to enhance silvicultural techniques for species such as Caryocar brasiliense Cambess, a tropical tree of the Caryocaceae family. This tree ("pequi") has significant economic relevance in the Cerrado biome because of its food and wood uses, as well as the oil extracted from its seeds (used in cosmetic and pharmaceutical industries). This species received the protected status due to its many uses, and these trees cannot be legally cut for lumber in Brazil (Almeida \& Silva, 1994; Silva Neto \& Costa, 2010).

Considering the wide distribution of this species in the Cerrado environment with irregular distribution of rainfall, characteristic of "Cerradão" (Ribeiro \& Walter, 1998), it is believed that $C$. brasiliense seedlings can be cultivated for a few days under water restriction. The aim of this study was to investigate the characteristics of the photosynthetic metabolism of $C$. brasiliense seedlings to determine their tolerance to water deficits and subsequent metabolic recuperation after rehydration.

\section{MATERIALS AND METHODS}

\subsection{Place of conduction of the experiment and production of seedlings}

The following experiments were carried out under greenhouse conditions located in the municipality of Dourados, Mato Grosso do Sul State, Brazil (22 $2^{\circ} 13^{\prime} 16^{\prime \prime} S, 54^{\circ} 17^{\prime} 01^{\prime \prime} \mathrm{W}$; 430 ma.s.l.). The regional climate is classified as Savanna climate (Aw) with an average annual rainfall of $1500 \mathrm{~mm}$ and of $22{ }^{\circ} \mathrm{C}$ (Kottek \& Grieser, 2006; Pinto et al., 2016).

Caryocar brasiliense Cambess ("pequi") seedlings were produced from seeds harvested in a native population in the Cerrado region of southern Mato Grosso do Sul State. Seedlings were cultivated in polyethylene planters (capacity $5 \mathrm{~kg}$ ) in a substrate composed of $50 \%$ distroferric Red Latosols and $50 \%$ sand (v:v), under $30 \%$ shading. The experiment started 20 months after sowing. The seedlings presented 6 to 9 expanded leaves and were between 16.3 and $18.5 \mathrm{~cm}$ tall, with stem diameters varying between 3.22 and $4.52 \mathrm{~mm}$ and primary roots between 24.0 and $31.0 \mathrm{~cm}$ long.

The cultivation planters were hydrated to $70 \%$ of their soil water retention capacity (WRC) (Souza et al., 2000).

\subsection{Water regimes}

The seedlings were divided in two groups:

1 - The first group (Control) was irrigated daily during the entire experiment period, and the soil was maintained at $70 \%$ of its water retention capacity.
2 - The second group (Stress) had it irrigation suspended until the photosynthetic rates of the seedlings approached zero (12 days after the suspended irrigation). Starting at photosynthetic zero, all pots were watered daily. The plants were maintained at $70 \%$ of the water retention capacity until recovery, when the seedlings under water deficit treatment reached similar levels of photosynthesis as those of the Control group (11 days after the rehydration, 23 days after the start of the experiment). During the experiments, the seedlings were maintained in an environment protected from natural rainfall.

\subsection{Characteristics evaluated}

Gas exchange: Internal carbon concentrations ( $C i-\mu \mathrm{mol}$ $\left.\mathrm{CO}_{2} \mathrm{~mol}^{-1}\right)$; stomatal conductance $\left(\mathrm{gs}-\mathrm{mol} \mathrm{m}^{-2} \mathrm{~s}^{-1}\right)$; transpiration rate $\left(E-\mathrm{mmol} \mathrm{m}{ }^{-2} \mathrm{~s}^{-1}\right)$; and photosynthetic rate $\left(\mathrm{A}-\mu \mathrm{mol} \mathrm{m}^{-2} \mathrm{~s}^{-1}\right)$ were determined using an infrared gas analyzer (IRGA) (ADC, model LCi PRO; Analytical Development Co. Ltd, Hoddesdon, UK). From the gas exchange data, two ratios were calculated - instantaneous water-use efficiency $(A / E$ $\left.\mu \mathrm{mol} \mathrm{CO} / \mathrm{mmol}^{-1} \mathrm{H}_{2} \mathrm{O}\right)$ and instantaneous carboxylation efficiency $\left(A / C i \mu \mathrm{mol} \mathrm{m}^{-2} \mathrm{~s}^{-1} / \mu \mathrm{mol} \mathrm{mol}^{-1}\right)$.

The chlorophyll index: was obtained using a Konica Minolta, SPAD 502 chlorophyll analyzer.

Efficiency of photosystem II: The potential quantum efficiency of photosystem II $\left(F_{v} / F_{m}\right)$ was determined using a portable fluorometer (model OS-30p) (Opti-Sciences Chlorophyll Fluorometer, Hudson, USA). Fluorescence determination was performed between 8 a.m. and 11 a.m., on the same leaves used to assess gas exchanges. They were subject to a period of 30-minute dark adaptation, using leaf-clip holders. This enabled the reaction centers in the foliar region to acquire the "open" configuration, indicating the complete oxidation of the photosynthetic electron transport system.

All measurements were performed between 8 a.m. and 11 a.m. starting the seventh day after suspending irrigation. All measurements were performed on the same expanded leaf.

\subsection{Evaluations periods}

Five seedlings were used in each treatment and the evaluations occurred $7,10,12,14,16,18,20,23$, and 27 days after suspending the water supply. The irregular intervals between evaluations reflect the necessity of performing the measurements under appropriate climatic conditions, i.e. sunny days without clouds. The evaluations were finished when the photosynthetic rate of the stressed seedlings approached that of the control seedlings. 


\subsection{Statistical delineation and data analysis}

For gas exchanges, the design was completely randomized with two water regimes - periodic irrigation, (Control) and no irrigation (Stress) - and five repetitions - each repetition representing a different seedling. After normality (Lilliefors test) and homogeneity (Bartlett test) tests, the results were subjected to analysis of variance. The means of each treatment were subjected to a t-test at $5 \%$ probability in the Sisvar statistical program when statistical significance occurred.

\section{RESULTS}

The mean photosynthetic rate $(A)$ of the control seedlings of $C$. brasiliense was $7.485 \mu \mathrm{mol} \mathrm{m} \mathrm{m}^{-2} \mathrm{~s}^{-1}$ (Figure 1a). When seedlings were subjected to water stress conditions a pronounced decrease in their photosynthetic rates until the seventh day occurred. By the 12th day their photosynthetic rates approached zero $\left(0.280 \mu \mathrm{mol} \mathrm{m} \mathrm{m}^{-2} \mathrm{~s}^{-1}\right)$, after which irrigation was reinitiated.
This rehydration of the seedlings exposed to conditions of water stress enabled them to recuperate their photosynthetic metabolism and regain high photosynthetic levels. The C. brasiliense seedlings required only 11 days to recuperate their initial photosynthetic rates.

The transpiration rates $(E)$ of the water stressed seedlings reduced similarly to the photosynthetic rate. The transpiration values of the stressed seedlings were lower than those of the control during the entire evaluation period (Figure $1 \mathrm{~b}$ ). The transpiration rates of the stressed seedlings was higher after rehydration, although the final values never reached those for the control (6.26 and $8.55 \mathrm{mmol} \mathrm{m}^{-2} \mathrm{~s}^{-1}$ respectively).

The water-use efficiency $(A / E)$ of the seedlings exposed to water deficit conditions was lower than that of the controls until the 14th day of evaluation (Figure 1c); however, after rehydration the $A / E$ values were higher than those of the control, reaching their peak on the 20th day (average $1.96 \mu \mathrm{mol} \mathrm{CO}_{2}$ / $\mathrm{mmol} \mathrm{H}_{2} \mathrm{O}$ ). The control seedlings had an average $A / E$ of $0.99 \mu \mathrm{mol} \mathrm{CO} / \mathrm{mmol}^{-1} \mathrm{H}_{2} \mathrm{O}$, below the value observed in stressed seedlings (average 1.27).

(a)

(b)

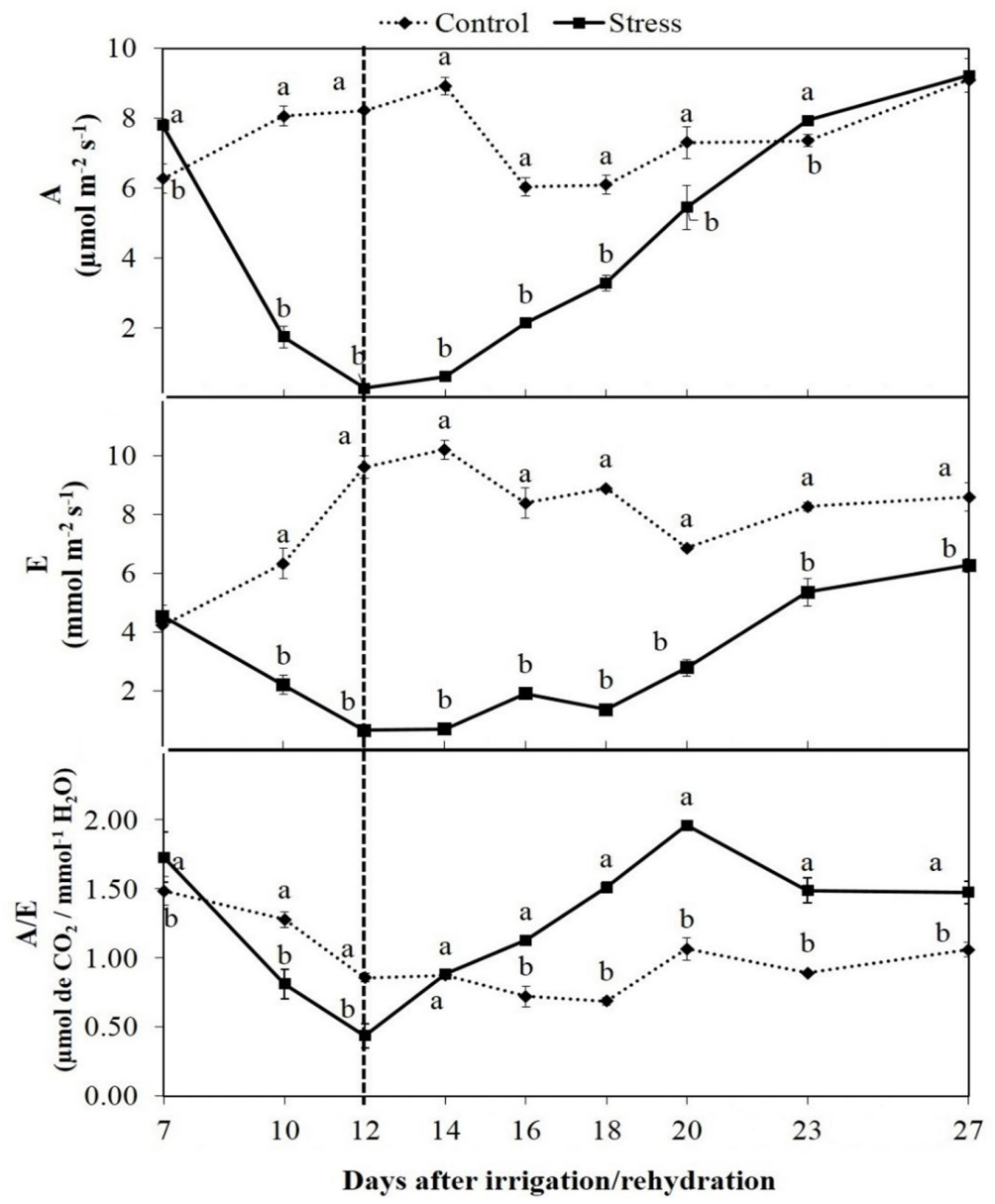

Figure 1. Mean values of photosynthetic rate - A (a), transpiration rate - E (b), water use efficiency - A/E (c) of Caryocar brasiliense Cambess seedlings subjected to intermittent water deficit. Means followed by different letters differ by t-test at $5 \%$ probability. 
The internal $\mathrm{CO}_{2}$ concentrations $(\mathrm{C} i)$ of the seedlings did not show the same response to the water deficit as the photosynthetic rate did (Figure 2a). Starting at the 14th day of evaluation the seedlings presented a decrease in their internal $\mathrm{CO}_{2}$ concentrations, with a small recovery by the 18th day, although they did not reached the same values as the control.

The instantaneous carboxylation efficiency $(\mathrm{A} / \mathrm{Ci})$ of the stressed seedlings was greater than that observed in the control, demonstrating an accentuated decrease between the 7 th and 10th day of experiment, with rapid recuperation after rehydration, surpassing the control again by the 18th day (Figure $2 b$ ).
Figure $2 c$ presents the stomatal conductance $(g s)$ of nearzero values by the 12 th day $\left(0.03 \mathrm{~mol} \mathrm{~m}^{-2} \mathrm{~s}^{-1}\right)$. Conductance values recovered slowly after rehydration, but they did not achieve initial values of the control in the end of the experimental period.

The chlorophyll index of the $C$. brasiliense seedlings varied little with the seedlings exposed to water deficit conditions, showing greater mean values than did the controls between the 14th and 18th days of evaluation (Figure $3 \mathrm{a}$ ).

The PS II quantum efficiency values $(\mathrm{Fv} / \mathrm{Fm})$ of the stressed seedlings strongly decreased. After rehydration, this efficiency increased after the 18th day, showing an average of 0.78 during subsequent evaluations (Figure $3 \mathrm{~b}$ ).

(a)

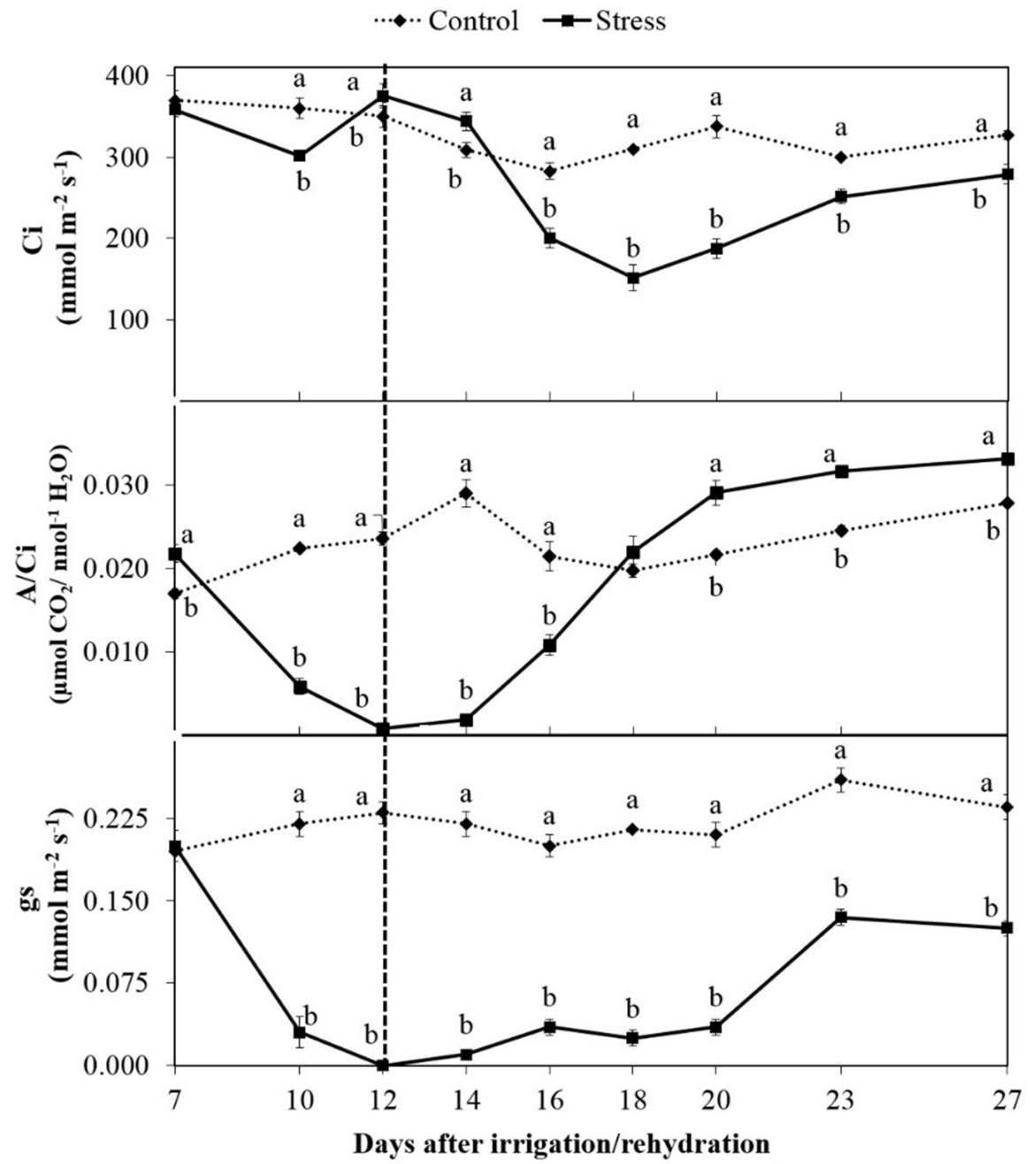

Figure 2. Mean values of internal $\mathrm{CO}_{2}$ concentration - $\mathrm{Ci}$ (a), instantaneous carboxylation efficiency of $\mathrm{CO}_{2}-\mathrm{A} / \mathrm{Ci}(\mathrm{b})$ and stomatal conductance - gs (c) of seedlings of Caryocar brasiliense Cambess subjected to intermittent water deficit. Means followed by different letters differ by t-test at $5 \%$ probability. 


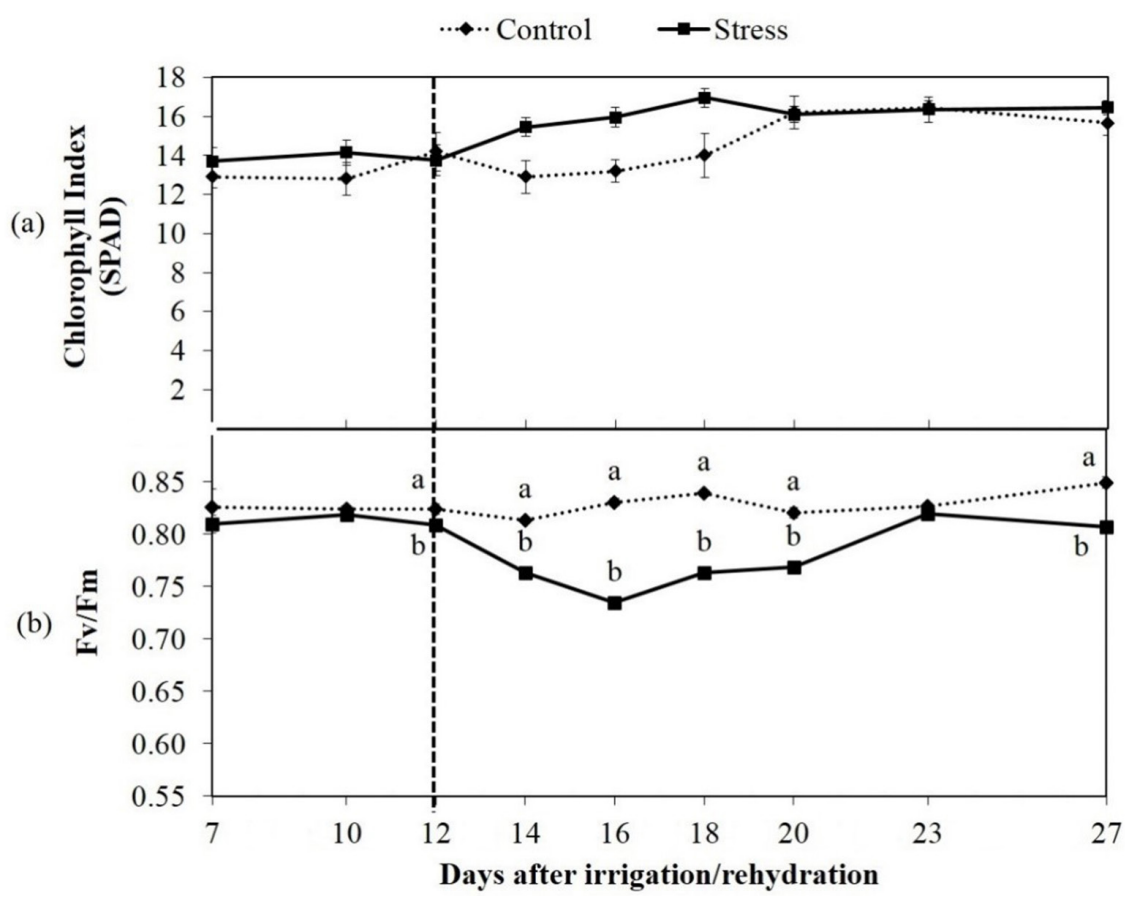

Figure 3. Mean values of chlorophyll index (SPAD) (a) and potential quantum efficiency of photosystem II (Fv /Fm) (b) and of seedlings of Caryocar brasiliense Cambess subjected to intermittent water deficit. Means followed by different letters differ by t-test at $5 \%$ probability.

\section{DISCUSSION}

The observed decreases in the photosynthetic rates $(A)$ of $C$. brasiliense seedlings could be attributed to reductions in their stomatal conductance, as it has been observed in other plant species by Dias \& Marenco (2007). This closing mechanism reduces transpiration and diminishes internal $\mathrm{CO}_{2}$ concentrations in the mesophyll, thus gradually halting the photosynthetic processes of water stressed plants.

According to Pacheco et al. (2011), plants exposed to water stress conditions normally present higher concentrations of abscisic acid (ABA) - a hormone that affects many physiological and developmental characteristics in plants). ABA has also been identified as a messenger for water stress perception (and other environmental stress factors).

A reduction in stomatal conductance $(g s)$ in C. brasiliense seedlings was observed on the seventh day after suspending irrigation; transpiration remained stable and low until approximately the 14th day, although photosynthesis was drastically reduced on the seventh day of evaluation. Transpiration in control plants increased throughout the experiment, which can be attributed to the high number of days without rain and with high temperature, factors that also contributed to raising the vapor pressure deficit (personal observation).

After rehydration, $g s$ values slowly recovered but did not attain the mean values of the control, suggesting that the stomata of this species are slow to recover after rehydration. The decrease in $A / E$ was observed in both control and stressed plants, suggesting a rapid stress response, even in the control seedlings which received water through soil. Furthermore, the increased $A / E$ above control values is related to the incomplete recovery of $g s$, leading to reduction of $E$.

These results were caused by low water availability in the plants that may decrease leaf water potential, resulting in the loss of turgor, which consequently reduced stomatal conductance and photosynthetic rate (Medrano et al., 2002). These results suggest the existence of adaptive mechanisms in C. brasiliense that can diminish water losses under water stress conditions.

The stomatal conductance of $C$. brasiliense seedlings decreased during the first 12 days after interrupting irrigation, indicating that the $g s$ response reflected decreased soil moisture. This result suggests the existence of connection between the plants roots and the aerial portion intermediated by growth substances, probably ABA (produced in roots), that enabled maintenance of water levels in leaves for longer periods, even though the soil is progressively drying (Gomes et al., 2004; Magalhães Filho et al., 2008).

The fact that $g s$ was reduced and $\mathrm{Ci}$ remained elevated in the seedlings until re-initiating irrigation suggests that other factors act in controlling photosynthesis. According to Medrano et al. (2002) and Parry et al. (2002), drought conditions reduce metabolism in the mesophyll by diminishing the activation 
and activity of rubisco carboxylase. The lower efficiency of rubisco may also be the result of greater mesophyll resistance due to stomatal closure, restricting the absorption of $\mathrm{CO}_{2}$ by the chloroplasts and increasing the action of rubisco oxygenase and (consequently) photorespiration. This result can be visualized by the rapid reduction in $A / C i$, which represents the instantaneous carboxylation efficiency of $\mathrm{CO}_{2}$ by rubisco. The recuperation of $g s$ in C. brasiliense was proportionally slower than that of $A$, which would explain the decrease in $C i$ after the rehydration of the leaf tissues.

There were notable continuations of various metabolic processes after rehydration. This led to an increase in wateruse efficiency due to a significant increase in photosynthetic processes and the maintenance of transpiration levels, reaching maximum values (1.96) by the 20th day ( 8 days after rehydration). These stressed plants attained values slightly higher than those of the control seedlings.

Responses to water deficits vary among plant species. Mariano et al. (2009) evaluated the effects of water stress conditions on the physiological characteristics of Myracrodruon urundeuva Allemão and observed similar tendencies to those seen in C. brasiliense, with transpiration showing a direct relationship with stomatal conductance, resulting in less diffusion of $\mathrm{CO}_{2}$ into the leaves and consequently reductions in photosynthetic levels. The photosynthetic indicators in young Carapa guianensis Aubl. plants decreased in water deficit conditions, reaching a near-zero photosynthetic rate at 21 days; the recovery of these indicators was observed approximately 8 days after rehydration, reestablishing all of the photosynthetic characteristics of normally irrigated plants (Gonçalves et al., 2009).

Campomanesia adamantium (Cambes.) O. Berg plants subjected to water deficit conditions demonstrated markedly decreased stomatal conductance and transpiration between the $23 \mathrm{rd}$ and the 31 st day. At the 31st day, the photosynthetic rate, water-use efficiency, and Rubisco carboxylation activity reached levels of almost zero, but when the plants were rehydrated, the metabolism recovered rapidly (Junglos et al., 2016).

Water deficit decreases the water potential in the leaves and all the traits of the photosynthetic metabolism in Campomanesia xanthocarpa Mart. ex O. Berg seedlings in 20 days of suspension of irrigation. These seedlings later recovered with the re-establishment of the water supply. However, the exposure of the seedlings to a second cycle of water deficit during the evaluation period demonstrated that the metabolism traits do not re-establish equilibrium (Bento et al., 2016).

In relation to PS II photochemical quantum efficiency, it was observed that water deficits did not cause any permanent damage to the photosynthetic apparatus. Subsequent means of 0.82 indicated recuperation of the photosynthetic rate and $F_{\sqrt{ }} / F_{\mathrm{m}}$ values. Plants with intact photosynthetic apparatus will have maximum chlorophyll fluorescence values $\left(F_{v} / F_{\mathrm{m}}\right)$ between 0.75 and 0.85 (Bolhar-Nordenkampf et al., 1989), with any decrease in this ratio reflecting photo inhibitory damage to the PSII reaction centers (Björkman \& Demming 1987; Thach et al., 2007).

The results obtained in this work indicate that the water stress conditions experienced by C. brasiliense seedlings were not severe enough to provoke photo-inhibition, and that the light collector complex of photosystem II was not damaged. These results are similar to those reported by Queiroz et al. (2002) in M. urundeuva Allemão seedlings, as the control seedlings had average values of 0.804 while seedlings after 14 days without irrigation demonstrated values of 0.798 .

The maintenance of high chlorophyll levels in seedlings cultivated in water deficit regimes can be attributed to the fact that less hydration resulted in apparent higher concentrations of these pigments in the cells. Although the chlorophyll index increased under water deficit conditions, a yellowing of the leaves was observed, indicating chlorosis. Water deficits represent one of the environmental stress factors responsible for pigment losses in leaves, due to ABA-induced relocation of metabolites to other parts. This relocation within the plant causes alterations in photosynthetic rates and alterations of the growth cycle. Coscolin et al. (2011) noted in their review that reductions in chlorophyll and protein levels can be characteristic symptoms of oxidative stress in plants exposed to low soil water availability, representing the beginning of leaf senescence.

The data obtained in this study indicate that C. brasiliense seedlings exposed to water stress conditions show reduced photosynthetic activities (reaching nearzero values 12 days after suspending irrigation). This reduction occurred because of limitations in the stomatal conductance and low rubisco carboxylation efficiency rather than irreversible damage to photosystem II. All of these parameters initiated their recuperation after rehydration, but only the photosynthetic rate fully attained initial values (11 days after rehydration).

These results suggest that $C$. brasiliense seedlings can be cultivated with periods of water restriction in a greenhouse or in areas of reforestation, where the periods of water deficit do not exceed 12 days. Further studies should be carried out under field conditions to assess more accurately how these plants behave when planted directly in the soil in full sun. 


\section{CONCLUSIONS}

Exposure to water deficit conditions reduced the values all of the parameters examined in C. brasiliense with the exception of the chlorophyll index. The stressed seedlings required only 12 days to approach zero for their photosynthetic rate, but they were able to reestablish photosynthetic equilibrium 11 days after rehydration. The water deficit did not cause any deleterious effects on the photosynthetic apparatus of the studied seedlings.

\section{ACKNOWLEDGEMENTS}

The authors are grateful for the financial support by Fundação de Apoio ao Desenvolvimento do Ensino, Ciência e Tecnologia do Estado de Mato Grosso do Sul (Fundect-MS), the Coordenação de Aperfeiçoamento de Pessoal de Nível Superior (CAPES) and Conselho Nacional de Desenvolvimento Científico e Tecnológico (CNPq).

\section{SUBMISSION STATUS}

Received: 23 Apr. 2017

Accepted: 22 Oct. 2018

Associate editor: Evânia Galvão Mendonça

\section{CORRESPONDENCE TO}

\section{Silvana de Paula Quintão Scalon}

Universidade Federal da Grande Dourados (UFDG), Rodovia Dourados Itahum, km 12, Bairro Rural, CEP 79804-970, Dourados, MS, Brasil.

e-mail: silvanascalon@ufgd.edu.br

\section{FINANCIAL SUPPORT}

Fundação de Apoio ao Desenvolvimento do Ensino, Ciência e Tecnologia do Estado de Mato Grosso do Sul (0071/09).

\section{REFERENCES}

Almeida SP, Silva JA. Piqui e buriti: importância alimentar para a população dos cerrados. Planaltina: Embrapa-CPAC; 1994. (Documentos, 54).

Bento LF, Scalon SPQ, Dresch DM, Pereira ZV. Potential for recovery of Campomanesia xanthocarpa Mart. ex O. Berg seedlings from water deficit. African Journal of Agricultural Research 2016; 11(30): 2775-2785. 10.5897/AJAR2016.11231

Björkman $\mathrm{O}$, Demming B. Photon yield of $\mathrm{O}_{2}$ evolution and chlorophyll fluorescence chracteristics at $77 \mathrm{k}$ among vascular plants of diverse origins. Planta 1987; 170(4): 61-66. 10.1007/BF00402983

Bolhar-Nordenkampf HR, Lon SP, Baker NR, Oquist G, Schreider U, Lechner EG. Chlorophyll fluorescence as a probe of the photosynthetic competence of leaves in the field: a review of current instrumentation. Functional Ecology 1989; 3(4): 497-514. 10.2307/2389624
Camejo D, Rodríguez P, Morales MA, Dell'Amico JM, Torrecillas A, Alarcón JJ. High temperature effects on photosynthetic activity of two tomato cultivars with different heat susceptibility. Journal of Plant Physiology 2005; 162(3): 281-289. 10.1016/j.jplph.2004.07.014

Chartzoulakis K, Patakas A, Kofidis G, Bosabalidis A, Nastou A. Water stress affects leaf anatomy, gas exchange, water relations and growth of two avocado cultivars. Scientia Horticulture 2002; 95(1-2): 39-50. 10.1016/S0304-4238(02)00016-X

Coscolin RBS, Broetto F, Marchese JA, Campohermoso MC, Paladini MV. Effects of hydric deficiency on gas exchange parameters and metabolism of Eucalyptus grandis clones. Brazilian Journal of Plant Physiology 2011;23(4): 255-262. 10.1590/S1677-04202011000400002

Dias DP, Marenco RA. Fotossíntese e fotoinibição em mogno e acariquara em função da luminosidade e temperatura foliar. Pesquisa Agropecuária Brasileira 2007; 42(3): 305-311. 10.1590/S0100-204X2007000300002

Durães FOM, Magalhães PC, Gama EEG, Oliveira AC. Caracterização fenotípica de linhagens de milho quanto ao rendimento e à eficiência fotossintética. Revista Brasileira de Milho e Sorgo 2005; 4: 355-361. 10.18512/1980-6477/rbms.v4n3p355-361

Franco AC. Relações hídricas em plantas do cerrado: As plantas lenhosas do cerrado transpiram livremente? In: Prado CHBA, Casali CA. Fisiologia vegetal: práticas em relações hídricas, fotossíntese e nutrição mineral. Barueri: Manole; 2006.

Gomes MMA, Lagôa AMMA, Medina CL, Machado EC, Machado MA. Interactions between leaf water potential, stomatal conductance and abscisic acid content of orange trees submitted to drought stress. Brazilian Journal of Plant Physiology 2004; 16(3): 155-161. 10.1590/S1677-04202004000300005

Gonçalves JFC, Silva CEM, Guimarães DG. Fotossíntese e potencial hídrico foliar de plantas jovens de andiroba submetidas à deficiência hídrica e à reidratação. Pesquisa Agropecuária Brasileira 2009; 44(1): 8-14.

Junglos FS, Junglos MS, Dresch DM, Pereira NS, Kodama FM, Scalon SPQ. Recovery of the photosynthetic capacity of Campomanesia adamantium (Myrtaceae) after water deficit. Brazilian Journal of Botany 2016; 39(2): 541-546. 10.1007/s40415-016-0275-X

Klink CA, Machado RB. Conservação do cerrado brasileiro. Megadiversidade 2005; 1(1): 147-155.

Kottek M, Grieser J, Beck C, Rudolf B, Rubel F. World map of the Köppen-Geiger climate classification updated. Meteorologische Zeitschrift 2006; 15(3): 259-263. 10.1127/0941-2948/2006/0130

Magalhães Filho JR, Amaral LRD, Machado DFSP, Medina CL, Machado EC. Deficiência hídrica, trocas gasosas e crescimento de raízes em laranjeira 'Valência' sobre dois tipos de porta enxertos. Bragantia 2008; 67(1): 75-82. 10.1590/S0006-87052008000100009

Mariano KRS, Barreto LS, Silva AHB, Neiva GKP, Ribeiro AJ, Amorim SMC. Fotossíntese e tolerância protoplasmática foliar em Myracrodruon urundeuva Fr. All. Revista Floresta 2009; 39(4): 853-859. 10.5380/rf.v39i4.16320

Medrano H, Escalona JM, Bota J, Gulias J, Flexas J. Regulation of photosynthesis of $\mathrm{C} 3$ plants in response to progressive drought: stomatal conductance as a reference parameter. Annals of Botany 2002; 89(7): 895-905. 10.1093/aob/mcf079 
Pacheco AC, Camargo PR, Souza CGM. Deficiência hídrica e aplicação de ABA nas trocas gasosas e no acúmulo de flavonoides em calêndula (Calendula officinalis L.). Acta Scientiarum Agronomy 2011; 33(2): 275-281. 10.4025/actasciagron.v33i2.6390

Parry MAJ, Andralojc PJ, Khan S, Lea PJ, Keys AJ. Rubisco activity: effects of drought stress. Annals of Botany 2002; 89(7): 833-839. 10.1093/aob/mcf103

Pinto JVC, Vieira MC, Zárate NAH, Formagio ASN, Cardoso CAL, Carnevali TO, Souza PHN. Effect of soil nitrogen and phosphorus on early development and essential oil composition of Schinus terebinthifolius Raddi. Journal of Essential Oil-Bearing Plants 2016; 19(1): 247-257. 10.1080/0972060X.2014.977561

Queiroz CGS, Garcia QS, Lemos Filho JP. Atividade fotossintética e peroxidação de lipídios de membrana em plantas de aroeira-do-sertão sob estresse hídrico e após reidratação. Brazilian Journal of Plant Physiology 2002; 14(1): 59-63. 10.1590/S1677-04202002000100008
Ribeiro JF, Walter BMT. Fitofisionomias do bioma cerrado. In: Sano SM, Almeida SP, editors. Cerrado: ambiente e flora. Planaltina: Embrapa-CPAC; 1998. p. 89-166.

Silva EC, Nogueira RJMC, Vale FHA, Araújo FP, Pimenta MA. Stomatal changes induced by intermittent drought in four umbu tree genotypes. Brazilian Journal of Plant Physiology 2009; 21(1): 33-42. 10.1590/S1677-04202009000100005

Silva Neto SP, Costa CJ. Importância econômica, social e ambiental do pequizeiro. Planaltina: Embrapa Cerrados; 2010.

Souza CC, Oliveira FA, Silva IF, Amorim Neto MS. Avaliação de métodos de determinação de água disponível e manejo da irrigação em terra roxa sob cultivo de algodoeiro herbáceo. Revista Brasileira de Engenharia Agrícola e Ambiental 2000; 4(3): 338-342. 10.1590/S1415-43662000000300006

Thach LB, Shapcott A, Schmidt S, Critchley C. The OJIP fast fluorescence rise characterizes Graptophyllum species and their stress responses. Photosynthesis Research 2007; 94(2-3): 423-436. 10.1007/s11120-007-9207-8 